Keywords:

- Kara Terrane

- Severnaya Zemlya Archipelago

- Granites

- Island arc magmatism

- Baltica

- Electronic Supplement 1: U-Pb zircon data.

- Electronic Supplement 2: Ar-Ar data.

- Electronic Supplement 3: Rb-Sr data.

- Electronic Supplement 4: Whole-rock geochemical data.

\section{The first evidence of Late Ordovician magmatism of the October Revolution Island (Severnaya Zemlya archipelago, Russian High Arctic): geochronology, geochemistry and geodynamic settings}

\author{
Mikhail Kurapov ${ }^{1}$, Victoria Ershova ${ }^{1,2}$, Andrei Khudoley ${ }^{1}$, Alexander Makariev ${ }^{3} \&$ \\ Elena Makarieva $^{3}$ \\ ${ }^{1}$ St. Petersburg State University, University nab. 7/9, St. Petersburg, 199034, Russia \\ ${ }^{2}$ Geological Institute, Russian Academy of Sciences, Pyzhevsky lane 7, Moscow, 109017 Russia \\ ${ }^{3}$ Polar Marine Geosurvey Expedition, 24, Pobedy st., St. Petersburg - Lomonosov, 198412, Russia \\ E-mail corresponding author(Mikhail Kurapov): Mikhail.kurapov@gmail.com
}

\begin{abstract}
We present a comprehensive study of Late Ordovician (Sandbian) granitic rocks from the southeastern part of October Revolution Island in the Severnaya Zemlya archipelago (Kara Terrane). U-Th-Pb zircon ionmicroprobe data and Ar-Ar biotite dating from two samples allow us to determine a crystallisation age for the intrusions at c. $457 \mathrm{Ma}$. Based on their geochemical and isotopic composition, the granites can be defined as I-type, suggesting island-arc magmatism development within Kara Terrane in the Late Ordovician. This arc magmatism may be correlated with the Mid-Late Ordovician early stage of the Caledonian Orogeny. The obtained data support a tectonic model proposing that the Kara Terrane represented a marginal part of Baltica during the Early to Middle Palaeozoic.
\end{abstract}

\section{Introduction}

Received:

11. January 2020

Accepted:

30. August 2020

Published online:

26. October 2020
The Severnaya Zemlya archipelago is located in the Russian High Arctic to the north of Siberia (Fig. 1A). It is composed of four large islands: Bol'shevik, October Revolution, Pioneer and Komsomolets, as well as a number of smaller islands (Fig. 1B).

Severnaya Zemlya and the northern part the Taimyr Peninsula together constitute the southern part of the Kara Terrane (North Kara terrane, Kara block) (Metelkin et al., 2005; Lorenz et al., 2008a, b; Drachev et al., 2011). A large part of this terrane is submerged beneath waters of the Kara Sea and therefore only available for geophysical study (Daragan-Suschova et al., 2013).

Kurapov, M., Ershova, V., Khudoley, A., Makariev, A. \& Makarieva, E. 2020: The first evidence of Late Ordovician magmatism of the October Revolution Island (Severnaya Zemlya archipelago, Russian High Arctic): geochronology, geochemistry and geodynamic settings. Norwegian Journal of Geology 100, 202016. https://dx.doi.org/10.17850/njg100-3-4. 
(A)

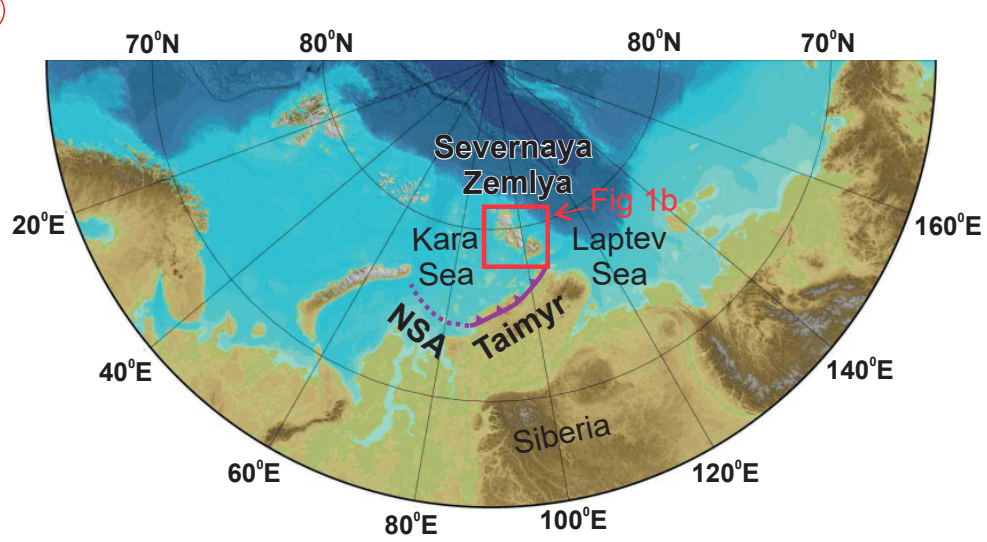

a) Suture between Kara Terrane and Siberia

b ....... b) Possible offshore boundaries of Kara Terrane

(B) NSA - North Siberian Arch

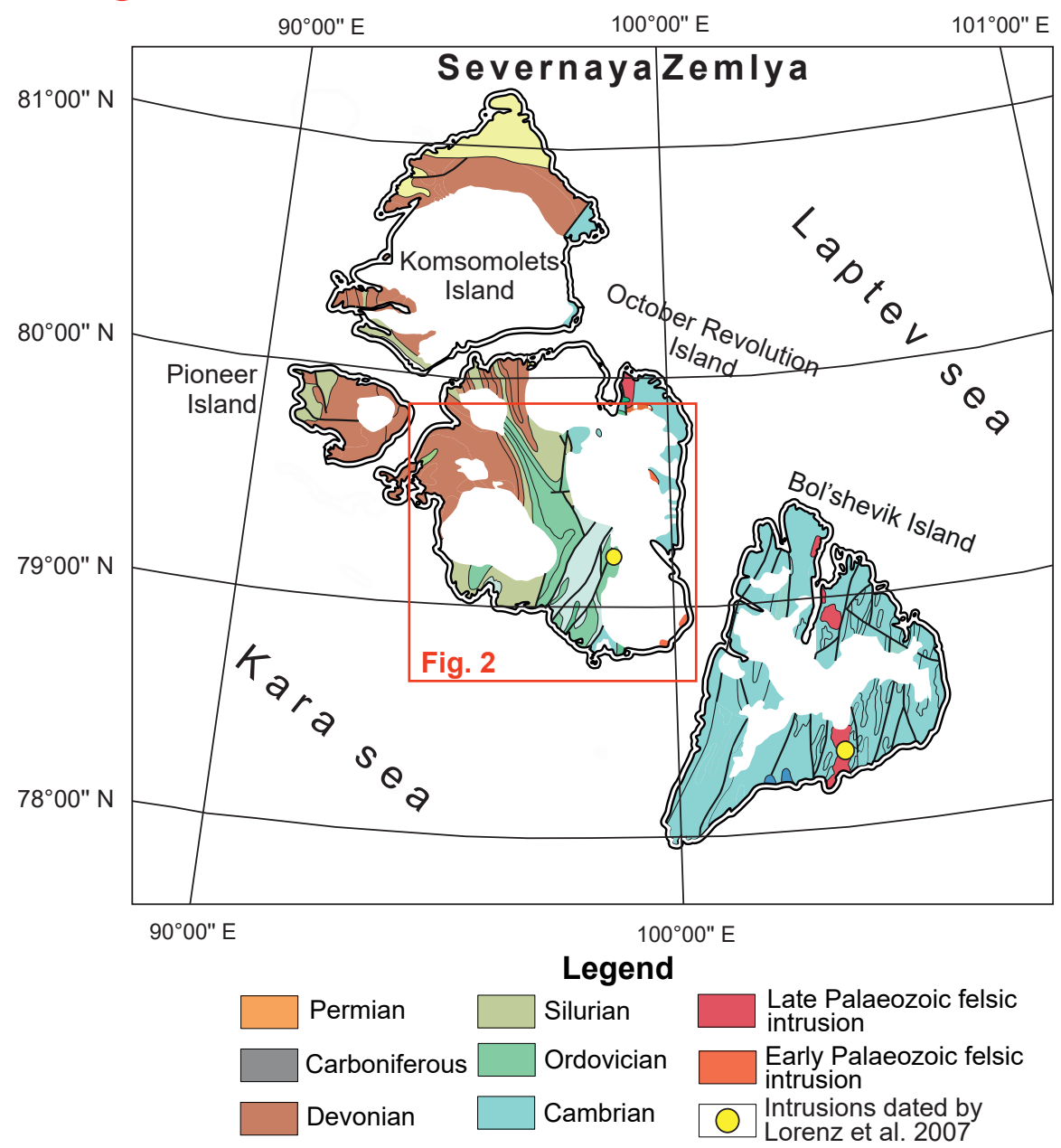

Figure 1. (A) Map of the Arctic region (modified after (Ershova et al., 2015b)) (B) Simplified map of Severnaya Zemlya archipelago with location of the studied area (modified after (Makariev, 2012; Ershova et al., 2018)). 
There are a number of different tectonic models for the affinity of the Kara Terrane in the Palaeozoic. Based on geological data, Zonenshain et al. (1990) suggested that the Kara Terrane formed part of a larger continent called Arctida, that also included the New Siberian Islands, Chukotka, the Seward Peninsula, North Greenland and the Canadian Arctic Archipelago. However, Metelkin et al. (2005) considered the Kara Terrane as an independent crustal block based on paleomagnetic data. According to Lorenz et al. (2008a), the Kara Terrane represented a marginal part of Baltica, based on lithology and structural data, supported by Ediacaran zircons found in deformed metasedimentary rocks, which were derived from the Timanian margin of Baltica, that has also been proved by a number of recent detrital zircon studies (Lorenz et al., 2008a, b; Pease \& Scott, 2009; Ershova et al., 2015a, b, 2018, 2020). Also, Lorenz et al. (2008a) showed that magnetic anomalies related to Ordovician intrusive rocks on October Revolution Island and Carboniferous granites on Bol'shevik Island can be traced across the Kara Sea and onto the Barents Shelf, thus sustaining the Baltican affinity of the Kara Terrane.

The Palaeozoic sedimentary, metasedimentary and magmatic rocks of the Kara Terrane crop out across the Severnaya Zemlya archipelago. This paper presents new geochronological and geochemical data from a granitic body that was intruded into lowermost Palaeozoic rocks along the southeastern part of October Revolution Island. Our new study of the magmatic rocks supports correlation of the Ordovician magmatic and tectonic events of the Kara Terrane and Caledonide Orogen, which provides a new insight into the geodynamic history of the Kara Terrane and paleotectonic reconstructions of the Arctic.

\section{Geological background}

The sedimentary succession of the Severnaya Zemlya archipelago comprises strata of Cambrian to Permian age (Fig. 2) (Lorenz et al., 2008b; Makariev, 2012; Ershova et al., 2015c, 2016). Pioneer, October Revolution and Komsomolets islands are mainly composed of Cambrian to Upper Devonian deposits with locally distributed Carboniferous and Permian strata. Predominantly Cambrian-Ordovician deposits are exposed on Bol'shevik Island, with a few outcrops of Upper Carboniferous-Permian and Mesozoic deposits (Makariev, 2012; Ershova et al, 2016, 2018).

The geological structure of the archipelago is dominated by a major NW-SE-trending anticline through the centre of October Revolution Island (Lorenz et al., 2008b). In the core of this anticline, Lower and Middle Ordovician, disharmonically folded, evaporite-bearing strata are exposed, with Upper Ordovician to Silurian terrigenous and carbonate strata on its limbs. The main structures to the northeast and southwest of the Al'banov Glacier Anticline are the Krasnaya Bay and Pioneer Island synclines, respectively (Lorenz et al., 2008b). In both of these structures, Silurian to Middle Devonian strata are exposed (Mannik et al., 2009).

Along with sedimentary strata, Palaeozoic granitic intrusions are widespread within the Severnaya Zemlya archipelago. Lorenz et al. (2007) performed U-Th-Pb SIMS analyses of zircons from several Ordovician volcanic and intrusive rocks across the central part of October Revolution Island. In their study, tuffs yielded ages between $489.5 \pm 2.7$ and $482.0 \pm 4.2 \mathrm{Ma}$, and a plagiogranite yielded an age of $474.4 \pm 3.5 \mathrm{Ma}$. Furthermore, Lorenz et al. (2007) described a Carboniferous granite intrusion on Bolshevik Island with U-Pb zircon ages from two samples of $342.0 \pm 3.6$ and $343.5 \pm 4.1 \mathrm{Ma}$.

The studied intrusion forming the basis for this study is located in the southeastern part of October Revolution Island (Fig. 2). It is exposed as a relatively small intrusive body (about $4 \mathrm{~km}^{2}$ ) cutting through Cambrian metasedimentary rocks, located on Cape Massivniy at the edge of University Glacier. Four samples were taken from the intrusion (Fig. 2): three from the central part (07208-1, 07110-1, 07110-7) and one from the rim (07208-2). 


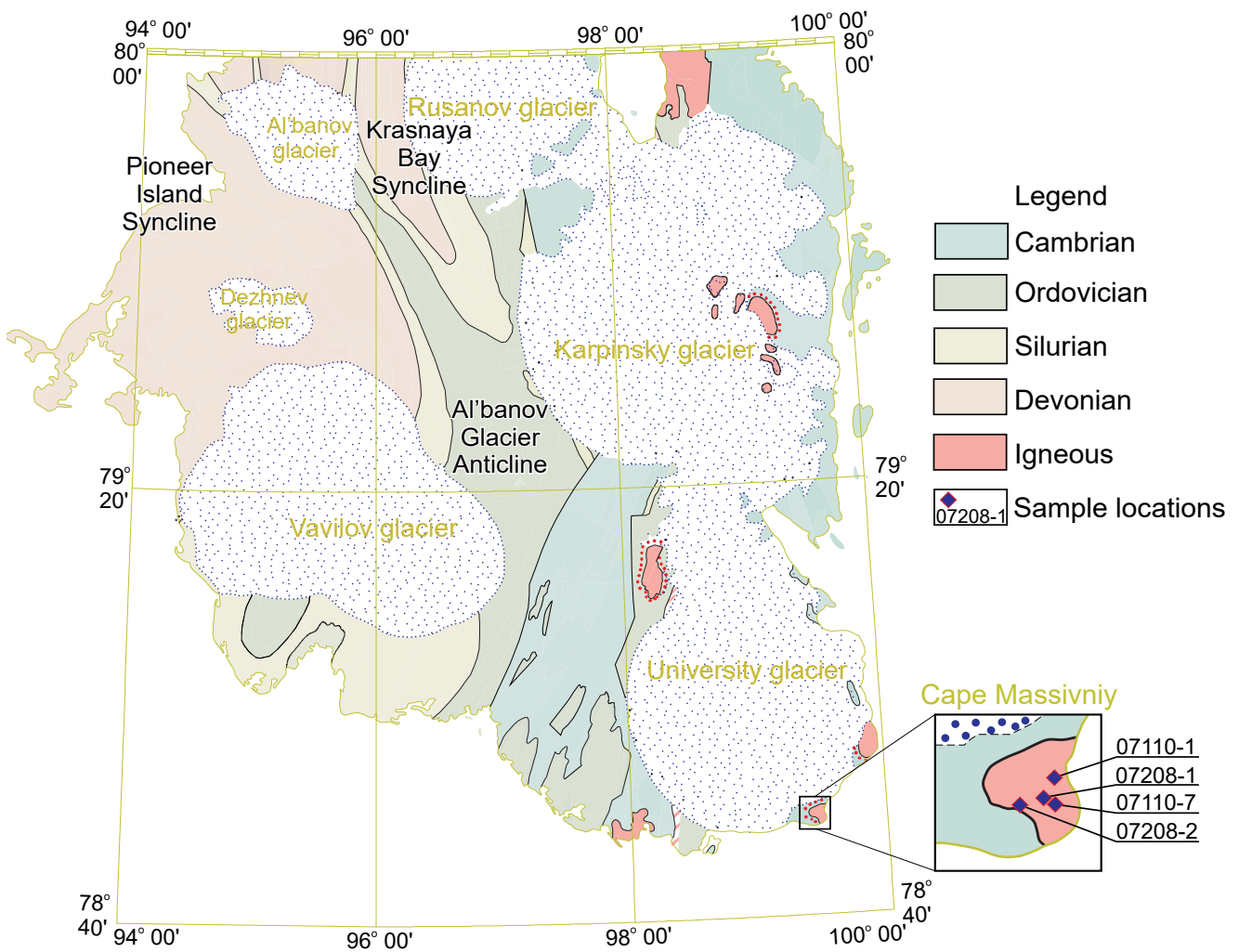

Figure 2. Simplified geological map of October Revolution Island (modified after Makariev, 2012) with location of studied samples.

\section{Methods}

$\mathrm{U}-\mathrm{Pb}$ dating of zircons was carried out with a sensitive high-resolution ion microprobe SHRIMP-II ion microscope at the Center of Isotopic Research, Russian Geological Research Institute (VSEGEI), St. Petersburg. Separation of zircons was performed according to the standard procedure including pulverisation to fragments approximately $0.25 \mathrm{~mm}$ in size, a centrifugal concentrator, removal of the highly magnetic minerals and processing with heavy liquids. The hand-picked zircon grains were mounted in the epoxy disc along with fragments of the zircon standards TEMORA and 91500. They were polished to expose the centres of the grains. For data point selection, cathodoluminescent images reflecting the internal structure and zoning of zircon were used. U-Pb ratios were measured following the technique described by Williams (1998). Each analysis consisted of 5 scans through the mass range, where the diameter of the spot was $15 \times 10 \mu \mathrm{m}$, and the primary beam intensity was $2.5-4.0 \mathrm{nA}$. The collected data were processed in the SQUID program (Ludwig, 2000). U-Pb ratios were normalised to the standard TEMORA zircon, corresponding to an age of $416.75 \mathrm{Ma}$ (Black et al., 2003). Uncertainties in single analyses (ratios and ages) were brought to conformity at a level of $\pm 1 \sigma$, and uncertainties in calculated concordant ages at a level of $\pm 2 \sigma$. The ISOPLOT program was used to construct concordia plots (Ludwig, 2003). U-Pb dating results are provided in Electronic supplement 1.

Dating by the ${ }^{40} \mathrm{Ar} /{ }^{39} \mathrm{Ar}$ method was performed at the Sobolev Institute of Geology and Mineralogy, Siberian Branch, Russian Academy of Sciences in Novosibirsk, and the measurement technique is described in Travin et al. (2009). Biotite fractions were wrapped in aluminum foil and placed into quartz ampoule together with MCA-11 and LP-6 biotite standards. Irradiation was done in the cadmium-plated channel of a VVR-K scientific reactor at the Research Institute of Nuclear Physics. The gradient of the neutron flux did not exceed $0.5 \%$ of the sample size. Experimental stepwise heating was carried out in a 
quartz reactor with an externally heated oven. A blank run with ${ }^{40} \mathrm{Ar}\left(10 \mathrm{~min}\right.$ at $\left.1200^{\circ} \mathrm{C}\right)$ did not exceed $5 \times 10-10 \mathrm{ncm}^{3}$. Purification of argon was carried out with ZrAI SAES getters. The isotopic composition of argon was measured on a Noblegas 5400 mass spectrometer (Micromass, England). Measurement errors in the text and figures correspond to $\pm 1 \sigma$. Ar-Ar dating results are provided in Electronic supplement 2 .

The isotopic composition of $\mathrm{Sr}$ was determined at the Institute of Precambrian Geology and Geochronology, Russian Academy of Sciences. Rb and Sr were separated by a technology close to that described in Savatenkov et al. (2004). The isotopic compositions of $\mathrm{Rb}$ and $\mathrm{Sr}$ were measured on a TIMS TRITON in the static mode. The measurement accuracy was $\pm 0.5 \%$ for $\mathrm{Rb}$ and $\mathrm{Sr}, 0.05 \%$ for ${ }^{87} \mathrm{Rb} /{ }^{86} \mathrm{Sr}$ and $0.007 \%$ for ${ }^{87} \mathrm{Sr} /{ }^{86} \mathrm{Sr}(2 \sigma)$. Taking into account the correction to instrumental fractionation ${ }^{88} \mathrm{Sr} /{ }^{86} \mathrm{Sr}$ $=8.37521$ ), the weight average ${ }^{87} \mathrm{Rb} /{ }^{86} \mathrm{Sr}$ of $\mathrm{Sr}$ in standard $\mathrm{BCR}-1$ over the measurement period is $0.710241 \pm 0.000015(2 \sigma, n=10)$. The level of the blank run over the study period is $0.05-0.15 \mathrm{ng}$ for $\mathrm{Rb}$ and $0.1-0.5 \mathrm{ng}$ for $\mathrm{Sr}$. $\mathrm{Rb} / \mathrm{Sr}$ analysis results are provided in Electronic supplement 3.

Geochemical studies were carried out at the Central Laboratory of Russian Geological Research Institute (VSEGEI), St. Petersburg. The contents of major oxides were determined on an ARL 9800 XRF spectrometer. The contents of minor elements (including REE) were determined on an OPTIMA 4300DV emission spectrometer and an ELAN 6100 mass spectrometer. Geochemical data are provided in Electronic supplement 4 along with sample coordinates. Petrographic study of the rocks was performed using Olympus BX51 and Leica DM4000 P LED optical microscopes.

\section{Petrography}

Four samples (07208-1, 07208-2, 07110-1, 07110-7; locations provided in Fig. 2) were collected from an intrusion on Cape Massivniy. Three samples (07208-1, 07110-1 and 07110-7) were collected from the central part of the intrusion and one from its margin (07208-2).

Granite porphyries (Fig. 3A) constitute the central part of the intrusion on Cape Massivniy (samples 07208-1, 07110-1 and 07110-7 location provided on Fig. 2). The rocks are characterised by a coarse-grained porphyritic texture. Plagioclase $(35-40 \%)$ is subhedral and sharply twinned, quartz $(30-35 \%)$ is present in irregular grains of various size and ranges from mosaic grains with undulose extinction to granulated, microcline $(20-25 \%)$ is tabular with clearly seen grid twinning, and biotite (7-10\%) occurs in laths. Accessory apatite and zircon are also present.

Altered granite porphyry (sample 07208-2) was collected from the margin of the same intrusion. The rock texture (Fig. 3B) is porphyritic with a micro-aplitic groundmass in some places. Plagioclase $(40 \%)$ ranges from fresh to highly altered grains rich in sericite, quartz (40\%) is mostly present as straight-sided crystals, and K-feldspar (20\%) occurs as irregular grains of various sizes. The groundmass of the granite porphyry comprises secondary sericite and secondary quartz.

\section{Geochronology}

The U-Pb zircon ages and Ar-Ar biotite ages were obtained for two (07208-1, 07208-2) out of the four samples collected from the Cape Massivniy intrusion. Dating results define a Late Ordovician crystallisation age (c. $457 \mathrm{Ma}$ ) for this intrusion. 
(A)

07208-1
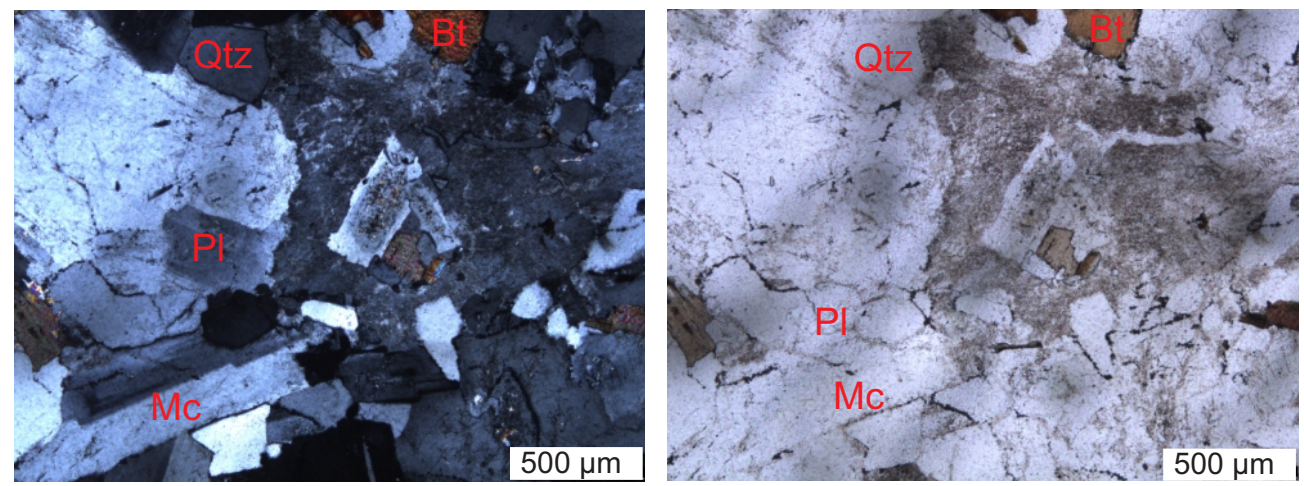

(B)

$07208-2$

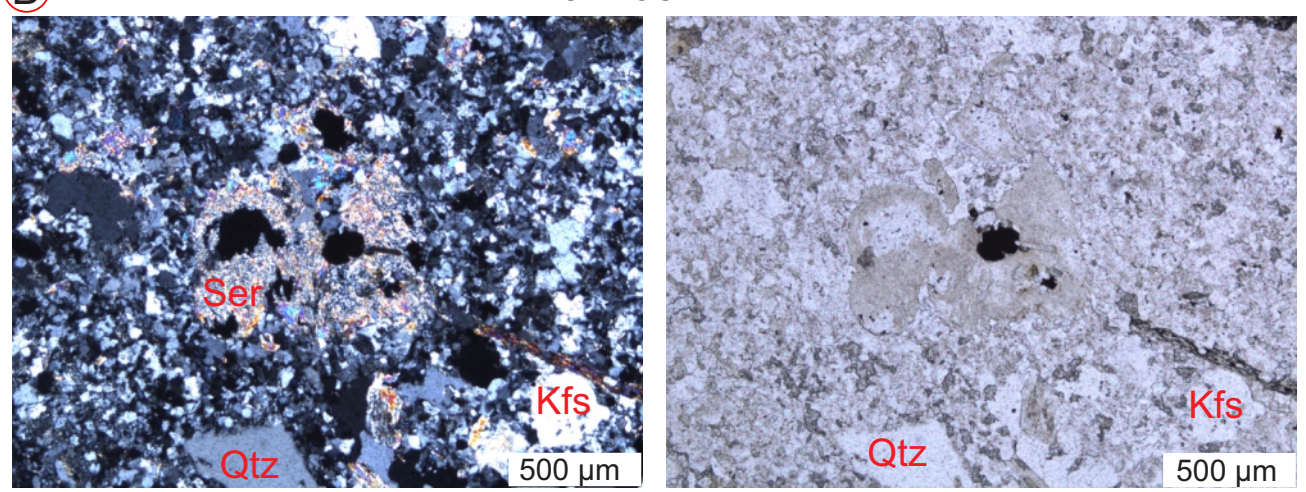

Figure 3. Photomicrograph of granite porphyry (A) 07208-1, (B) 07208-2 from Cape Massivniy. Qtz - quartz, $\mathrm{Pl}$-plagioclase, $\mathrm{Mc}$ - microcline, $\mathrm{Bt}$ - biotite, $\mathrm{Kfs}-\mathrm{K}$-feldspar, Ser-serecite.

Zircons from sample 07208-1 are heterogeneous and characterised by a euhedral shape and clearly visible oscillatory zoning (Fig. 4A). The $U$ content in the analysed fractions ranges from 81 to $803 \mathrm{ppm}$, with moderate Th/U ratios of $0.21-0.75$ (Electronic supplement 1 ), suggestive of a magmatic origin. All of the ten analysed grains yield concordia ages of $457 \pm 3 \mathrm{Ma}$ (Fig. 4A). Biotite from this sample yields a plateau age of $453.5 \pm 4.8 \mathrm{Ma}$ (Fig. 5, Electronic supplement 2), encompassing more than $95 \%$ of released Ar.

The zircon population from sample 07208-2 is heterogeneous. Prismatic grains with elongation ratios ranging from 2 to 5 dominate (Fig. 4B). The $U$ content in the analysed fractions ranges from 312 to 1602 $\mathrm{ppm}$ with Th/U ratios of $0.02-0.87$ (Electronic supplement 1 ). Nine out of the eleven analysed grains define a concordia age of $457 \pm 4.4 \mathrm{Ma}$ (Fig. 4B). Two other grains $(9.1 ; 11.1$ ) yield ages of 551.5 and 545.5 $\mathrm{Ma}$, and thus were most likely inherited from the enclosing rock. Biotite from this sample yields a plateau age of $443.5 \pm 4.4 \mathrm{Ma}$ (Fig. 5, Electronic supplement 2), encompassing $80 \%$ of released $\mathrm{Ar}$. The $\mathrm{Ar}-\mathrm{Ar}$ age is c. 14 million years younger than the $\mathrm{U}-\mathrm{Pb}$ zircon age, with the difference probably related to postmagmatic cooling or hydrothermal alteration of the granite. 
(A)

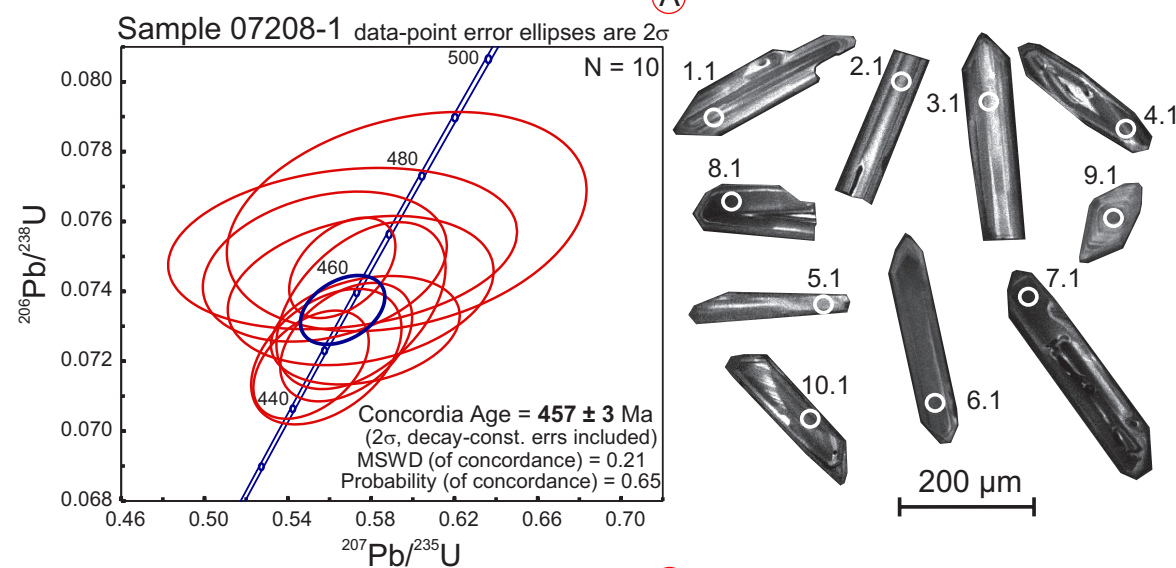

(B)

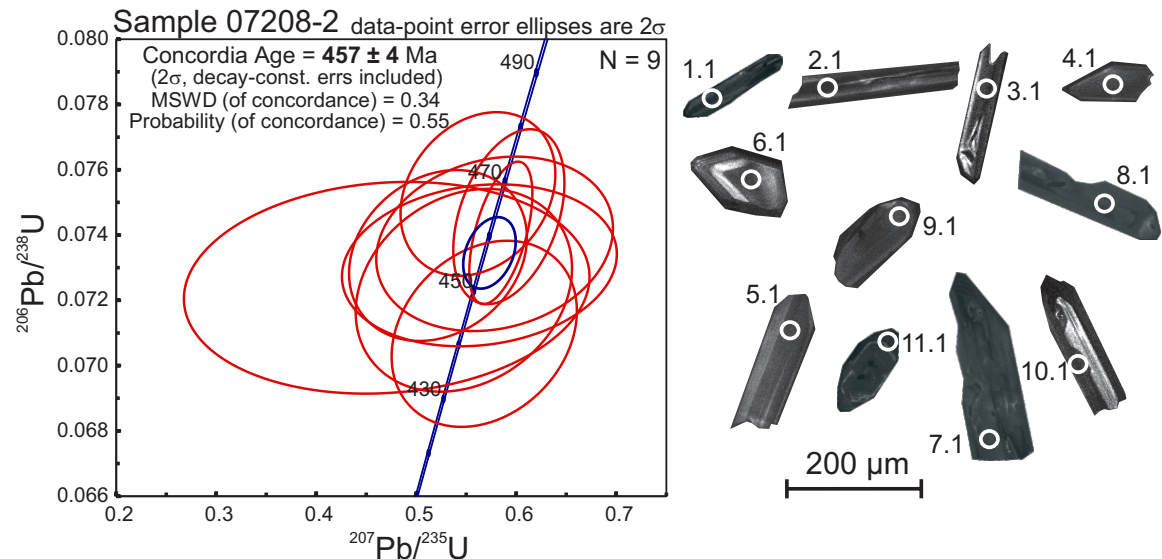

Figure 4. Concordia diagrams for granite porphyries from Cape Massivniy with BSE-CL images of zircon grains from the granite porphyries. $N$ - number of dated zircons. Circles show dated spots along with their numbers.
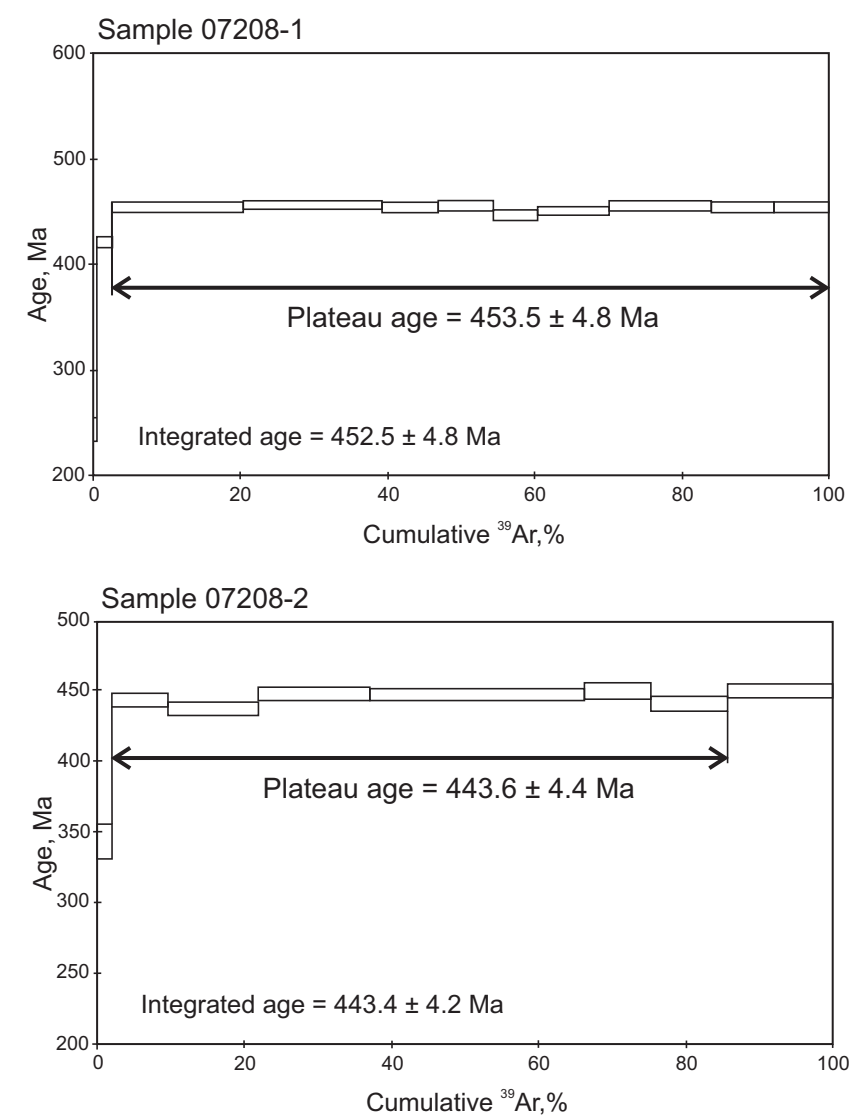

Figure 5. Ar-Ar spectra on muscovite and biotite from Ordovician granites from Cape Massivniy. 


\section{Geochemistry}

The studied granites (Electronic supplement 4) contain 69.3-74.4 wt.\% $\mathrm{SiO}_{2}$. According to the classification of Frost et al. (2001), the granites are magnesian to slightly ferroan $\left(\mathrm{Fe}^{*}=\mathrm{FeO}_{\text {tor }} /\left(\mathrm{FeO}_{\text {tot }}+\right.\right.$ $\mathrm{MgO})=0.74-0.79)$ (Fig. 6A), primarily calc-alkalic, alkali-calcic, and calcic (Fig. 6B) peraluminous rocks (Fig. 6C).

In a chondrite-normalised diagram (Sun \& McDonough, 1989), the granites have a REE distribution pattern (Fig. 7A) enriched in LREE and depleted in HREE $\left(\mathrm{La}_{N} / \mathrm{Yb}_{N}=7.19-11.44\right)$, with a negative Eu anomaly $\left(E u / E u^{*}=0.36-0.46\right)$. In a primitive mantle-normalised multi-element diagram (Sun \& McDonough, 1989), the trace elements show a distinct negative anomaly for Ba, Nb and Sr (Fig. 7B). On the Nb-Sr plot (Fig. 8A), the data points of granitoids cluster close to the mean value for I-type granites (Whalen et al., 1987). The samples plot in the boundary zone between fields characteristic of volcanic arcs and syn-collisional granites on the $\mathrm{Yb}$ vs. Ta and $(\mathrm{Y}+\mathrm{Nb})$ vs. Rb discrimination diagrams of Pearce et al. (1984) (Fig. 8B, C).

The initial ${ }^{87} \mathrm{Sr} /{ }^{86} \mathrm{Sr}$ ratios of the granites are 0.70092 and 0.70748 (Fig. 8D; Electronic supplement 4). A low initial ${ }^{87} \mathrm{Sr} /{ }^{86} \mathrm{Sr}$ ratio in sample $07208-2$ is due to advanced hydrothermal alteration of the rock as observed in the mineral composition. A value of 0.70748 for sample $07208-1$ is characteristic of island arc l-type granites (Lee et al., 2007), which is further supported by the calc-alkalic and magnesian character of the granites and negative anomalies for $\mathrm{Ba}, \mathrm{Nb}$ and $\mathrm{Sr}$ on the multi-element diagrams. The overall characteristics of the studied granites thus suggest that they can be classified as I-type granites (Pitcher, 1979; Armstrong et al., 1977; Chappell \& White, 2001).
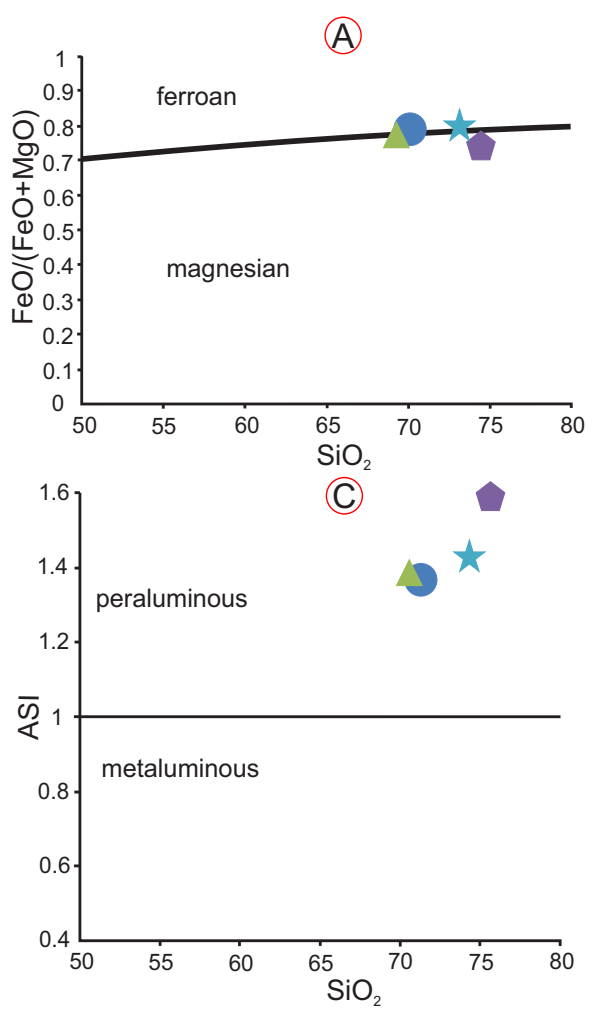

(B)

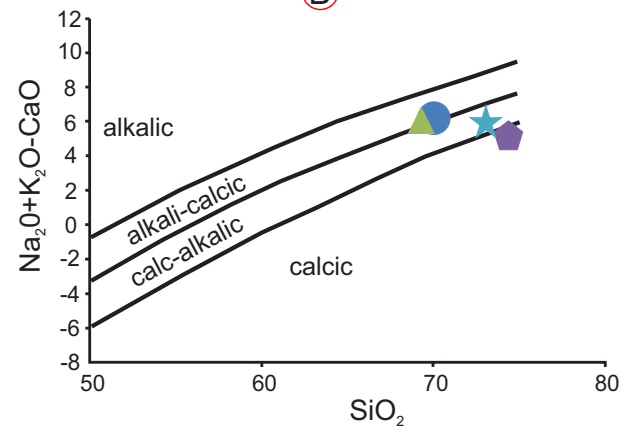

07110-1

$07208-1$

$07208-2$

$+07110-7$

Figure 6. (A) $\mathrm{FeO} /(\mathrm{FeO}+\mathrm{MgO})$ v. $\mathrm{SiO}_{2}$ diagram (B) $\mathrm{Na}_{2} \mathrm{O}+\mathrm{K}_{2} \mathrm{O}-\mathrm{CaO}$ v. $\mathrm{SiO}_{2}$ diagram. (C) ASI v. SiO diagram (Frost et al., 2001) for the studied granites. 

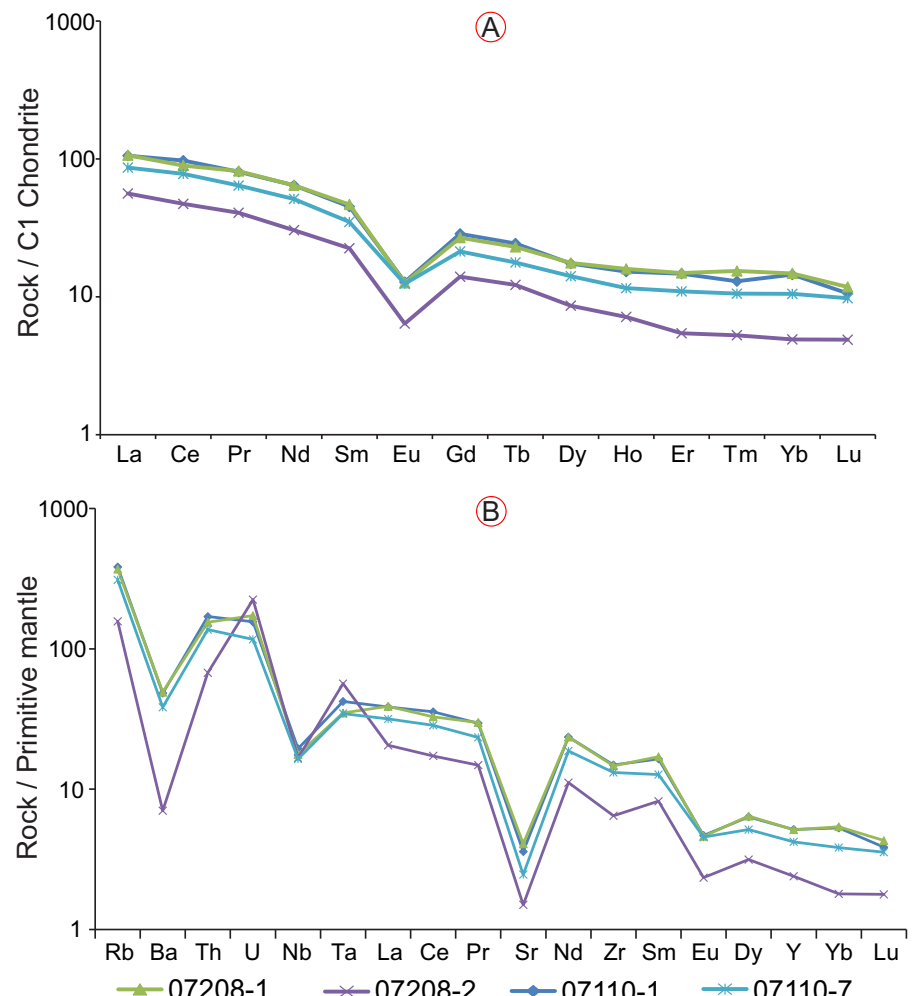

Figure 7. (A) Chondrite-normalised REE and (B) primitive mantle-normalised multi-element diagrams for studied Cape Massivniy granites. Chondrite and primitive mantle normalisation values from Sun and McDonough (1989).

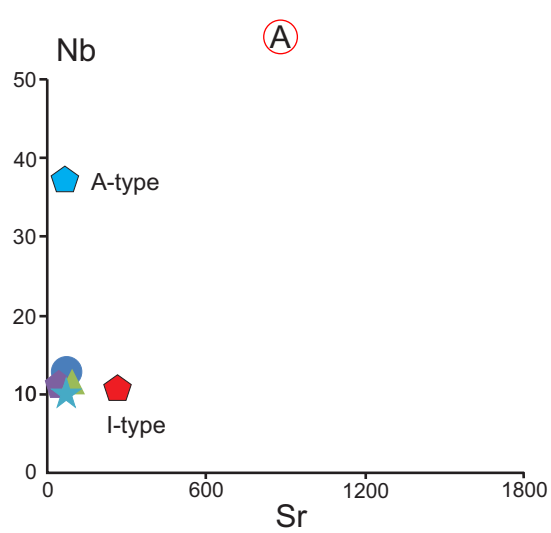

(C)

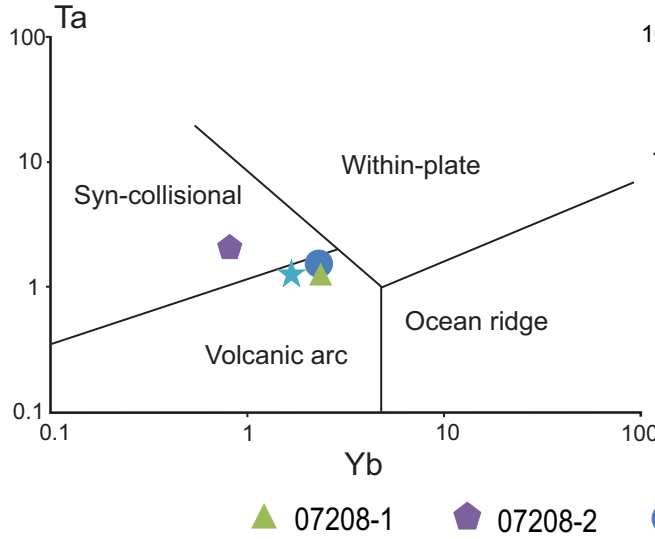

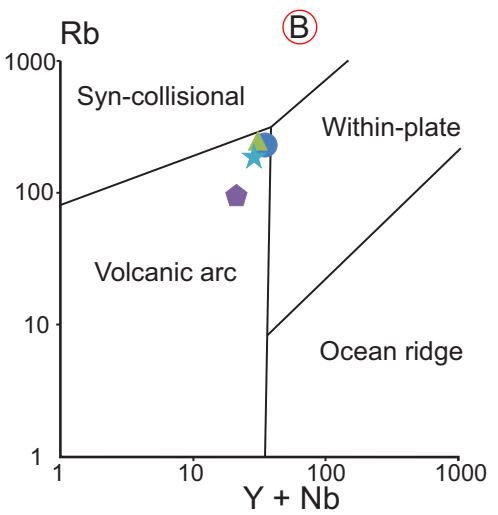

(D)

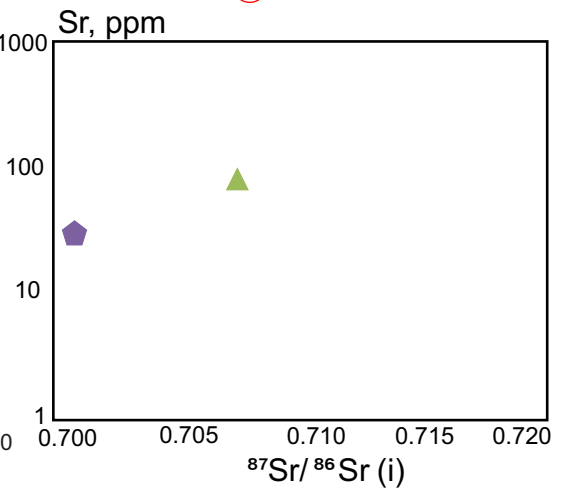

07110-1 $\star$ 07110-7

Figure 8. (A) Nb v. Sr (Whalen et al., 1987); (B) Rb v. Y + Nb; (C) Ta v. Yb discrimination diagrams of Pearce et al. (1984); (D) Sr ppm v. $\left({ }^{87} \mathrm{Sr} /{ }^{86} \mathrm{Sr}\right)$ i diagram for the Cape Massivniy Late Ordovician granites. 


\section{Discussion}

The October Revolution Island granites from Cape Massivniy (Fig. 2) yield U-Pb and Ar-Ar crystallisation ages of c. 457 (Sandbian, Late Ordovician). The petrographic, geochemical and isotopic characteristics of these granites are similar to subduction-related I-type granites, which likely were formed within a magmatic arc (Pitcher, 1979; Brown et al., 1984). This provides evidence of island-arc magmatism within the Kara Terrane during this time. Previous studies have described the Early Ordovician rift-related magmatic belt in the eastern part of the October Revolution Island (Proskurnin, 1999; Lorenz et al., 2007). Our new data thus reveal a separate, supra-subduction, magmatic event within October Revolution Island in the Late Ordovician.

Late Ordovician magmatism is not known from northern Siberia, although Mid-Late Ordovician island-arc granite intrusions are widely known throughout the Caledonides (Stephenson et al., 2000; Yoshinobu et al., 2002; Rhenström, 2010; Augland et al., 2012; Corfu et al., 2014a, b). Augland et al. (2012) have described Late Ordovician, magnesian alkali-calcic and calc-alkaline granitoids with an age of $446 \mathrm{Ma}$ from eastern Greenland, which were attributed to the products of an island arc situated near Laurentia. Island-arc granites of a similar age have been described from the Caledonides of Scotland (Stephenson et al., 2000; Corfu et al., 2014a) and Norway (Yoshinobu et al., 2002).

The Caledonides formed as the result of a collision between Baltica and Laurentia during closure of the lapetus Ocean. Northern Caledonian structures can be traced along the western and eastern margins of the Atlantic Ocean and represented by large thrust sheets (Gee et al., 2008, 2013; Johnston et al., 2010). In the west, the Greenland Caledonides consist of rocks of Laurentian affinity that were situated in the upper plate of the Caledonide Orogen. In the east, the Scandinavian Caledonides are marked by east- to southeastward thrusting and sequential stacking of allochthonous and para-autochthonous nappes onto the Baltoscandian margin, including both Baltican complexes and outboard terranes, some of Laurentian affinities (Roberts, 2003; Gee et al., 2008, 2013).

Our new data allow us to correlate the Late Ordovician granites of October Revolution Island with the Mid-Late Ordovician, island-arc granites of Greenland, Scotland and Norway (Stephenson et al., 2000; Yoshinobu et al., 2002; Augland et al., 2012; Corfu et al., 2014a). These intrusions are all of a similar age (c. 466-444 Ma, Fig. 9) and characterised by similar geochemical signatures. The Middle-Late Ordovician stage of the Caledonian Orogeny involved the development of island arcs in the closing lapetus Ocean (Roberts, 2003; Corfu et al., 2014b) followed by continental collision between Baltica and Laurentia in Middle Silurian to Early Devonian time (Roberts, 2003). The close similarity between the Late

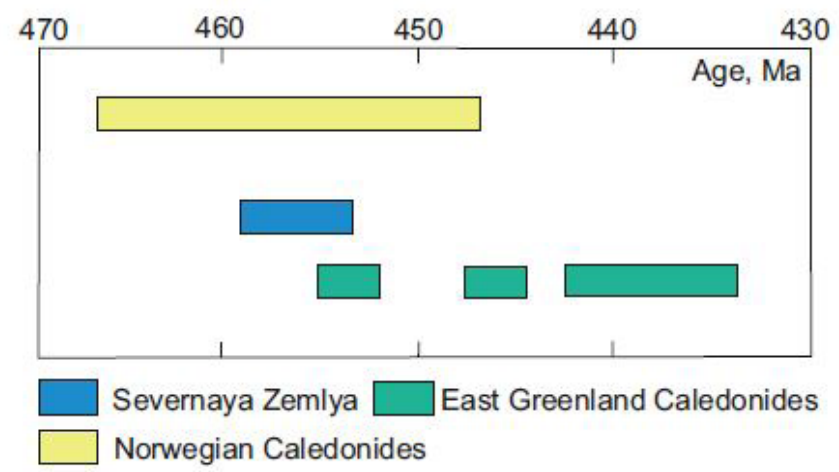

Figure 9. Diagram showing U-Pb zircon ages from arc-related granites of Severnaya Zemlya, East Greenland Caledonides (Augland et al., 2012) and the Norwegian Caledonides (Yoshinobu et al., 2002; Corfu et al., 2014a). 
Ordovician granites of the Severnaya Zemlya archipelago and known Mid-Late Ordovician granites from the Caledonides (Stephenson et al., 2000; Yoshinobu et al., 2002; Augland et al., 2012; Corfu et al., 2014a) suggests that all of these magmatic complexes were formed in association with subduction events in the lapetus Ocean. However, most of these granites are linked to westward subduction of lapetan oceanic crust beneath Laurentia (Yoshinobu et al., 2002; Augland et al., 2012; Corfu et al., 2014a).

The Kara Terrane was a part of northern Baltica during lapetus closure and the Caledonian Orogeny, therefore representing a part of the Baltoscandian margin. Baltica was rotating anticlockwise relatively fast in the Late Ordovician (Torsvik, 1997), and this could have involved various contractional and extensional settings parallel to its margin, resulting in widespread magmatism of different character (Youshinobu et al., 2002; Meyer et al., 2003; Corfu et al., 2006; Barnes et al., 2007; Augland et al., 2012). Formation of the magmatic-arc granite intrusion of October Revolution Island indicates a period of contraction and subduction which resulted in the generation of arc magmas.

The island-arc magmatism within the Kara Terrane and its connection to the lapetus Ocean supports a Baltican affinity for the Kara Terrane during the Early-Middle Palaeozoic, supporting the tectonic model of Lorenz et al. (2008a, b) and Ershova et al. (2015a, b, 2018) for the Arctic. Also, the ages of xenocrystic zircons of c. 546 and 551 Ma correlate with a described Timanian component in magmatic and sedimentary rocks in the Severnaya Zemlya Archipelago and Northern Taimyr (Lorenz et al., 2007; 2008a, b; Pease \& Scott, 2009; Ershova et al., 2015a, b; 2018; 2020). The presence of Timanian xenocrystic zircons in the studied granites also supports a Baltican affinity for the Kara terrane.

\section{Conclusions}

The studied granitic intrusions of the eastern part of October Revolution Island crystallised in the Late Ordovician (Sandbian) at c. $457 \mathrm{Ma}$. The geochemical composition of the studied plutons and initial ${ }^{87} \mathrm{Sr} /{ }^{86} \mathrm{Sr}$ ratio of 0.70748 suggests that they can be classified as I-type granites. Our data suggest the existence of an arc magmatism within the Kara Terrane in the Late Ordovician and therefore supports the tectonic model proposed by Lorenz et al. (2008a, b) and Ershova et al. (2015a, b), suggesting that the Kara Terrane formed a marginal part of Baltica in the Early-Middle Palaeozoic.

Acknowledgements. Fieldwork and geochronological dating were performed within the framework of compilation of the State Geological Map of the Russian Federation at a scale of $1: 1,000,000$. We are grateful to Dr. J. Barnet for discussion and correcting the English.

\section{References}

Armstrong, R.L., Taubeneck, W.H. \& Hales, P.O. 1977: Rb-Sr and K-Ar geochronometry of Mesozoic granitic rocks and their $\mathrm{Sr}$ isotopic composition, Oregon, Washington, and Idaho. Geological Society of America Bulletin 88, 97-411. .https://doi.org/10.1130/0016-7606(1977)88<397:RAKGOM>2.0.CO;2

Augland, L.E., Andresen, A., Corfu, F. \& Daviknes, H.K. 2012: Late Ordovician to Silurian ensialic magmatism in Liverpool Land, East Greenland: new evidence extending the northeastern branch of the continental Laurentian magmatic arc. Geological Magazine 149, 561-577.

https://doi.org/10.1017/S0016756811000781. 
Barnes, C.G., Frost, C.D., Yoshinobu, A.S., McArthur, K., Barnes, M.A., Allen, C.M., Nordgulen, $\varnothing$. \& Prestvik, T. 2007: Timing of sedimentation, metamorphism, and plutonism in the Helgeland Nappe Complex, north-central Norwegian Caledonides. Geosphere 3, 683-703. https://doi.org/10.1130/GES00138.1.

Black, L.P., Kamo, S.L., Allen, C.M., Heinikoff, J.N., Davis, D.W., Russel, J., Korsch, R.J. \& Foudonlis, C. 2003: TEMORA 1: A new zircon standard for U-Pb geochronology. Chemical Geology 200, 155-170. https://doi.org/10.1016/S0009-2541(03)00165-7.

Brown, G.C., Thorpe, R.S. \& Webb, P.C. 1984: The geochemical characteristics of granitoids in contrasting arcs and comments on magma sources. Journal of the Geological Society of London 141, 413-426. https://doi.org/10.1144/gsjgs.141.3.0413.

Chappell, B.W \& White, A.J.R. 2001: Two contrasting granite types: 25 years later. Australian Journal of Earth Sciences 48, 489-500. https://doi.org/10.1046/j.1440-0952.2001.00882.x.

Corfu, F., Torsvik, T.H., Andersen, T.B., Ashwal, L.D., Ramsay, D. M. \& Roberts, R.J. 2006: Early Silurian mafic-ultramafic and granitic plutonism in contemporaneous flysch, Mageroy, northern Norway: U-Pb ages and regional significance. Journal of the Geological Society, London 163, 291-301.

https://doi.org/10.1144/0016-764905-014.

Corfu, F., Andersen, T.B. \& Gasser, D. 2014a: The Scandinavian Caledonides: main features, conceptual advances and critical questions. Geological Society, London, Special Publications 390, 9-43. https://doi.org/10.1144/SP390.25.

Corfu, F., Gasser, D. \& Chew, D.M. 2014b: New Perspectives on the Caledonides of Scandinavia and Related Areas. Geological Society, London, Special Publications 390, 1-8. https://doi.org/10.1144/SP390.28.

Daragan-Suschova, L.A., Petrov, O.V., Daragan-Suschov, Yu. \& Vasiliev, M.A. 2013: Features of geological structure of the North-Kara shelf on seismic data. Regional Geology and Metallogeny 54 5-16 (In Russian).

Drachev, S.S., Malyshev, N.A. \& Nikishin, A.M. 2010: Tectonic history and petroleum geology of the Russian Arctic Shelves: an overview. Geological Society, London, Petroleum Geology Conference series 7, 591-619. https://doi.org/10.1144/0070591.

Ershova, V.B., Prokopiev, A.V., Khudoley, A.K., Shneider, G.V., Andersen, T., Kallerund, K., Makariev, A.A. \& Kolchanov, D.A. 2015a: U-Pb dating of detrital zircons from the Lower Paleozoic deposits of the North Kara basin. Doklady Earth Sciences 464, 444-447. https://doi.org/10.1134/S1028334X15100013.

Ershova, V.B., Prokopiev, A.V., Khudoley, A.K., Sobolev, N.N. \& Petrov, E.O. 2015b: Detrital zircon ages and provenance of the upper paleozoic successions of Kotel'ny island (New siberian islands archipelago). Lithosphere 7, 40-45. https://doi.org/10.1130/L387.1.

Ershova, V.B., Prokopiev, A.V., Nikishin, V.A., Khudoley, A.K., Nikishin, A.M. \& Malyshev, N.A. 2015c: New data on Upper Carboniferous Lower Permian deposits of Bol'shevik island, Severnaya Zemlya archipelago. Polar Research 34. https://doi.org/10.3402/polar.v34.24558.

Ershova, V., Prokopiev, A. \& Khudoley, A. 2016: Devonian-Permian sedimentary basins and paleogeography of the Eastern Russian Arctic: an overview. Tectonophysics 691, pp. 234-255. https://doi.org/10.1016/j.tecto.2016.03.026. 
Ershova, V., Anfinson, O., Prokopiev, A., Khudoley, A., Stockli, D., Faleide, J.I., Gaina, C. \& Malyshev, N. 2018: Detrital zircon (U-Th)/He ages from Paleozoic strata of the Severnaya Zemlya Archipelago: Deciphering multiple episodes of Paleozoic tectonic evolution within the Russian High Arctic. Journal of Geodynamics 119, 210-220. https://doi.org/10.1016/j.jog.2018.02.007.

Ershova, V., Prokopiev, A., Khudoley, A., Andersen, T., Kullerud, K. \& Kolchanov, D. 2020: U-Pb Age and $\mathrm{Hf}$ Isotope Geochemistry of Detrital Zircons from Cambrian Sandstones of the Severnaya Zemlya Archipelago and Northern Taimyr (Russian High Arctic). Minerals 10, 36.

https://doi.org/10.3390/min10010036.

Frost, B.R., Barnes, C.G., Collins, W.J., Richard, J.A., Ellis, D.J. \& Frost, C.D. 2001: A geochemical classification for granitic rocks. Journal of Petrology 42, 2033-2048.

https://doi.org/10.1093/petrology/42.11.2033.

Gee, D., Fossen, H., Henriksen, N. \& Higgins, A. 2008: From the Early Paleozoic Platforms of Baltica and Laurentia to the Caledonide Orogen of Scandinavia and Greenland. Episodes 31, 44-51.

https://doi.org/10.18814/epiiugs/2008/v31i1/007.

Gee, D.G. Janák, M., Majka J., Robinson P. \& van Roermund H. 2013: Subduction along and within the Baltoscandian margin during closing of the lapetus Ocean and Baltica-Laurentia collision. Lithosphere 5 , 169-178. https://doi.org/10.1130/L220.1.

Johnston, S., Hartz, E., Brueckner, H. \& Gehrels, G. 2010: U-Pb Zircon Geochronology and Tectonostratigraphy of Southern Liverpool Land, East Greenland: Implications for Deformation in the Overriding Plates of Continental Collisions. Earth and Planetary Science Letters 297, 512-524. https://doi.org/10.1016/j.epsl.2010.07.003.

Lee, C.T.A., Morton, D.M., Kistler, R.W. \& Baird, A.K. 2007: Petrology and tectonics of Phanerozoic continent formation: From island arcs to accretion and continental arc magmatism. Earth and Planetary Science Letters 263, 370-387. https://doi.org/10.1016/j.epsl.2007.09.025.

Lorenz, H., Gee, D.G. \& Whitehouse, M.J. 2007: New geochronological data on Paleozoic igneous activity and deformation in the Severnaya Zemlya Archipelago, Russia, and implications for the development of the Eurasian Arctic margin. Geological Magazine 144, 105-125.

https://doi.org/10.1017/S001675680600272X.

Lorenz, H., Mannik, P., Gee, D. \& Proskurnin, V. 2008a: Geology of the Severnaya Zemlya Archipelago and the North Kara Terrane in the Russian high Arctic. International Journal of Earth Sciences 97, 519-547. https://doi.org/10.1007/s00531-007-0182-2.

Lorenz, H., Gee, D.G. \& Simonetti, A. 2008b: Detrital zircon ages and provenance of the Late Neoproterozoic and Paleozoic successions on Severnaya Zemlya, Kara Shelf: a tie to Baltica. Norwegian Journal of Geology 88, 235-258.

Ludwig, K.R., 2000: SQUID 1.00, A User's Manual. Berkley Geochronology Center, Special Publication 2. Ludwig, K.R. 2003: Isoplot 3.00, A Geochronological Toolkit for Microsoft Excel. Berkley Geochronology Center, Special Publication 4, 1-74.

Makariev, A.A. (Ed.) 2012: State Geological Map of the Russian Federation. Scale 1:1 000000 (third generation), Sheet T-45 - 48th. Cheliuskin. VSEGEI publishing, St. Petersburg. 
Mannik, P., Bogolepova, O.K., Poldvere, A. \& Gubanov, A.P. 2009: New data on Ordovician-Silurian conodonts and stratigraphy from the Severnaya Zemlya Archipelago, Russian Arctic. Geological Magazine 146, 497-516. https://doi.org/10.1017/S0016756809006372.

Metelkin, D.V., Vernikovsky, V.A., Kazansky, A.Yu., Bogolepova, O.K. \& Gubanov, A.P. 2005: Paleozoic history of the Kara microcontinent and its relation to Siberia and Baltica: Paleomagnetism, paleogeography and tectonic. Tectonophysics 398, 225-243. https://doi.org/10.1016/j.tecto.2005.02.008.

Meyer, G.B., Grenne, T. \& Pedersen, R.B. 2003: Age and tectonic setting of the Neså Batholith: implications for Ordovician arc development in the Caledonides of Central Norway. Geological Magazine 140, 573-594. https://doi.org/10.1017/s0016756803008069.

Pearce, J.A., Harris, N.B.W. \& Tindle, A.G. 1984: Trace element discrimination diagrams for the tectonic interpretation of granitic rocks. Journal of Petrology 25, 956-983.

https://doi.org/10.1093/petrology/25.4.956.

Pease, V. \& Scott, R.A. 2009: Crustal affinities in the Arctic Uralides, northern Russia: significance of detrital zircon ages from Neoproterozoic and Paleozoic sediments in Novaya Zemlya and Taimyr. Journal of the Geological Society 166, 517-527. https://doi.org/10.1144/0016-76492008-093.

Pitcher, W.S. 1979: The nature, ascent and emplacement of granitic magmas. Journal of the Geological Society 136, 627-662. https://doi.org/10.1144/gsjgs.136.6.0627.

Proskurnin, V.F. 1999: On the problem of angular unconformities in the Upper Precambrian and Lower Paleozoic of the Severnaya Zemlya Archipelago. In Bowels of Taimyr (ed. O. N. Simonov.), pp. 68-76. Norilsk. (in Russian).

Rehnström, E.F. 2010: Prolonged Paleozoic magmatism in the East Greenland Caledonides: some constraints from U-Pb ages and Hf isotopes. Journal of Geology 118, 447-465.

https://doi.org/10.1086/655010.

Roberts, D. 2003: The Scandinavian Caledonides: event chronology, paleogeographic settings and likely modern analogues. Tectonophysics 365, 283-299. https://doi.org/10.1016/S0040-1951(03)00026-X.

Savatenkov, V.M., Morozova, I.M. \& Levsky, L.K. 2004: Behavior of the Sm-Nd, Rb-Sr, K-Ar, and U-Pb isotopic systems during alkaline metasomatism: Fenites in the outer-contact zone of ultramafic-alkaline intrusion. Geochemistry international 42, 899-920.

Stephenson, D., Bevins, R.E., Millward, D., Stone, P., Parsons, I., Highton, A.J. \& Wadsworth, W.J. 2000: Caledonian Igneous Rocks of Great Britain, Geological Conservation Review Series. Joint Nature Conservation Committee. No. 17, Peterborough, 648 pp.

Sun, S.S. \& McDonough, W.F. 1989: Chemical and isotopic systematics of oceanic basalts: Implications for mantle composition and processes. Geological Society, London, Special Publications 42, 313-345. https://doi.org/10.1144/GSL.SP.1989.042.01.19.

Torsvik, T. H. 1997: Palaeozoic palaeogeography: a North Atlantic viewpoint. GFF 120, 109-118. https://doi.org/10.1080/11035899801202109. 
Travin, A.V., Yudin, D.S., Vladimirov, A.G., Khromykh, S.V., Volkova, N.I., Mekhonoshin, A. \& Kolotilina, T.B. 2009: Thermochronology of the Chernorud granulite zone, Ol'khon region, Western Baikal area. Geochemistry international 47, 1107-1124. https://doi.org/10.1134/S0016702909110068.

Whalen, J.B., Currie, K.L. \& Chappell, B.W. 1987: A-type granites: geochemical characteristics, discrimination and petrogenesis. Contributions to Mineralogy and Petrology 95, 407-419. https://doi.org/10.1007/BF00402202.

Williams, I.S. 1998: U-Th-Pb geochronology by ion microprobe: Applications of microanalytical techniques to understanding mineralizing processes. Reviews in Economic Geology 7, 1-35.

https://doi.org/10.5382/Rev.07.01.

Yoshinobu, A.S., Barnes, C.G, Nordgulen, O., Prestvik, T., Fanning, M. \& Pedersen, R.B. 2002: Ordovician magmatism, deformation, and exhumation in the Caledonides of central Norway: An orphan of the Taconic orogeny?. Geology 30, 883-886.

https://doi.org/10.1130/0091-7613(2002)030<0883:OMDAEI>2.0.CO;2.

Zonenshain, L.P., Kuz'min, M.I. \& Natapov, L.M. 1990: Plate Tectonics of the USSR Territory. Nedra Vol. II, Moscow (in Russian). 